\title{
Grazing of barley stubble by sheep in Syria: effect of stocking rate, supplement type and level on apparent intake of stubble and on body weight change
}

\author{
S Rihawi 1, AV Goodchild 1, TT Treacher 2, E Owen ${ }^{3}$ \\ IInternational Center for Agricultural Research in the Dry Areas, P.O. Box 5466, Aleppo, Syria \\ ${ }^{2}$ ETSIAM, University of Cordoba, Apartado 3048, 14080 Cordoba, Spain; 3 Department of Agriculture, \\ University of Reading, P.O. Box 236, Reading, RG6 2AT, UK
}

In summer the grazed stubble (on-field postharvest residue) of barley or wheat crop is the main feed for sheep and goats in the Middle East. The stubble is practically free of weeds and contains less than $5 \%$ of spilt grain and less than $35 \mathrm{~g}$ crude protein ( $/ \mathrm{kg}$ DM). We studied the intake of morphological fractions of stubble, their contribution to nutrient content and the response of the body weight of grazing sheep to different stocking rates and to types and levels of supplement feeding.

There were three experiments (summers 1991, 1992, 1993). Areas of barley (Hordeum vulgare, Arabic Abiad landrace) were harvested with a combine harvester at a cutting height of $10 \mathrm{~cm}$. The cut straw was removed from the field. Stubble mass was estimated using ground-level quadrat cuts on 8 occasions during each 28 -day grazing period. The quadrat dimensions were $4.25 \mathrm{~m} \times 0.47 \mathrm{~m}$. Awassi sheep grazed paddocks of stubble at stocking rates of 20 and 40 sheep.ha ${ }^{-1}$ in all three years, and additionally at 60 sheep.ha-1 in 1991; access to grazing was between 6:30 and 18:30 hours. The stubble mass before grazing was $1045-1135 \mathrm{~kg}^{\mathrm{DM}}$.ha-1.

In 1992 additional groups were fed 200 g.d $\mathrm{d}^{-1}$ barley or $200 \mathrm{~g} . \mathrm{d}^{-1}$ cottonseed cake at each stocking rate. In 1993 there were four supplementation treatments (see table): the higher level of barley provided the same quantity of crude protein (CP) as the lower

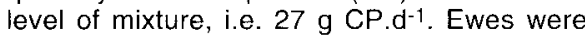
given access to rams at night during the

Year and

Animals

Supplement

1991 (wethers) None

1992 (ewes) None

Barley, $200{\mathrm{~g} . \mathrm{d}^{-1}}^{-1}$

1993 (ewes)

experiments of 1992 and 1993, and the service dates of ewes were recorded.

The apparent daily intake of stubble, measured as rates of reduction in quadrat yields over 2 or 5 days, decreased with time. In general, sheep selected heads in the first few days, followed by leaf, then stem as the availability of leaf decreased. After the middle of 28-day periods at the high stocking rates (40 or 60 sheep.ha-1) the availability and intake of stem itself decreased, resulting in daily stubble intakes of less than $0.70 \mathrm{~kg} . \mathrm{d}^{-1}$. As the 28-day periods progressed, sheep had declining intakes of metabolisable energy (ME, calculated from in vitro digestible organic matter using a factor of 15 MJ. $\mathrm{kg}^{-1}$ ). In 1991 and 1992, calculated ME intakes from stubble for sheep stocked at 20 or $40 \mathrm{ha}^{-1}$ were 13-17 MJ.d $\mathrm{d}^{-1}$ in the first 6 days, 6-10 MJ in the next 12 days and 2-6 MJ in the last 10 days. The average $\mathrm{CP} / \mathrm{ME}$ ratio of unsupplemented sheep fell from $6 \mathrm{~g} . \mathrm{MJ}^{-1}$ to $2 \mathrm{~g} \cdot \mathrm{MJ}^{-1}$. The pattern of changes of CP and ME intake for each supplementation treatment indicated that the level and type of supplement fed should vary according to the quantities of fractions of stubble left on the field.

Offering small amounts of supplement to ewes grazing barley stubble increased body weight at mating, and reduced the time required to conceive. Responses of body weight were greater in ewes receiving supplements with the higher protein concentrations.

Stubble intake

kg DM.sheep ${ }^{-1} \cdot d^{-1}$

Stocking rate, $\mathrm{ha}^{-1}$

$20 \quad 40 \quad 60$

$\begin{array}{lll}1.06 & 0.79 & 0.54\end{array}$

$1.10 \quad 0.83$

$1.15 \quad 0.85$

1.29

1.14

1.13

1.19

1.09

1.09
0.94

0.87

0.92

0.93

0.85

0.85
Body weight change in 28 days, $\mathrm{kg}$ Stocking rate, $\mathrm{ha}^{-1}$ $20 \quad 40 \quad 60$

$\begin{array}{lll}0.3 & -2.1 & -3.2\end{array}$

$-0.6 \quad-2.4$

$3.5 \quad 1.1$

$4.3 \quad 1.4$

$0.6-1.2$

$2.7 \quad 0.3$

$4.9 \quad 0.9$

$6.1 \quad 1.9$

8.34 .1 